\title{
SAMBUCUS EBULUS - FROM TRADITIONAL MEDICINE TO RECENT STUDIES
}

\author{
Oskan Tasinov, Yoana Kiselova-Kaneva, Diana Ivanova \\ Laboratory of Nutrigenomics, Functional Foods and Nutraceuticals, \\ Department of Biochemistry, Molecular Medicine and Nutrigenomics, \\ Medical University of Varna
}

\begin{abstract}
Sambucus ebulus L. (Dwarf elder) is an herbaceous plant well-known in traditional medicine of Bulgaria and other countries from Central Europe to the Middle East. It is used for treatment of inflammation-related gastrointestinal disorders, influenza, kidney and lung diseases, and rheumatoid arthritis as well as of wounds, snake and insect bites bites. Recent research of Dwarf elder shows a high content of total polyphenols, anthocyanin, quercetin and vitamin $\mathrm{C}$, which may be related to its antioxidant activity. Compounds with antiinflammatory and antinociceptive action such as chlorogenic and ursolic acids in the herb have been established, too. Some studies reveal anticancer properties of the herb, and plant ebulins are considered as the main compounds with anticancer properties. Fruit extracts modulate the gene expression of antioxidant enzymes in a preadipocyte cell culture model. Data available indicate that Dwarf elder is a good source of phytotherapeutic means to treat pathological conditions related to inflammation and oxidative stress.
\end{abstract}

Key words: Sambucus ebulus, traditional medicine, polyphenols, antioxidant effect, anti-inflammatory effect, antimicrobial effect

\section{INTRODUCTION}

Sambucus ebulus L. (SE) (Dwarf elder) is an herbaceous plant well-known in traditional medicine of Balkans and Anatolia for its healing effects in many disorders. It has been used for a long time for treatment of inflammation-related gastrointestinal disorders, influenza, kidney and lung diseases, and rheumatoid arthritis as well as of

\footnotetext{
Address for correspondence:

Diana Ivanova, PhD

Laboratory of Nutrigenomics,

Functional Foods and Nutraceuticals,

Dept. of Biochemistry, Molecular Medicine

and Nutrigenomics, Medical University of Varna

55 Marin Drinov Street, 9002 Varna, Bulgaria

tel: +359-52677075, mobile: $+359-888259786$

e-mail:divanova@mu-varna.bg
}

Received: February 10, 2013

Accepted: March 22, 2013 wounds, snake and insect bites. Traditional medicine provides more data about elderberry fruit usage as immune stimulator, for treatment of respiratory and gastrointestinal diseases, dropsy, and even as an anticancer agent $(16,22,31,39)$. Recent research reveals the phytochemical composition and many biological activities of SE in different study models. This review aims at summarizing the traditional use of this plant as a remedy and phytotherapeutic source useful in inflammation-related disorders.

\section{Botanical characteristics}

$\mathrm{SE}$ is an herbaceous species of genus Sambucus (elder or elderberry). Sambucus is a genus of flowering plants in Adoxaceae family formerly placed into Caprifoliaceae one, however, reclassified due to genetic evidence (7). It contains between 5 and 30 species of famous perennial herbaceous plants, deciduous shrubs, or small trees (26). In Bulgaria, there are three species such as SE (Dwarf elder), $S$. nigra (Black elder) and S. racemosa (European red 
elder). SE is a perennial plant with long, creeping and branched rhizome. It grows to $1-2 \mathrm{~m}$ in height, with erect, usually unbranched stems growing in large groups. Leaves are opposite, pinnate, $15-30 \mathrm{~cm}$ long, with 5-9 leaflets with a foetid smell. The stems terminate in a corymb of $10-15 \mathrm{~cm}$ in diameter with numerous white, occasionally pink flowers. The fruit is a small glossy, dark blue to violet black berry of 5-6 $\mathrm{mm}$ in diameter, juicy, with three pits. It is flowering from May to August and fruits ripen from August to September $(3,26)$.

\section{Distribution}

Dwarf elder also known as Dane weed, Danesblood, Danewort or European dwarf elder and Walewort is a species native to Southern and Central Europe and South-West Asia (43). Habitats include places near cities, roads, railways, through the bushes, near forests, rivers and as a weed in fields up to $1900 \mathrm{~m}$ of altitude (3).

\section{Usage in traditional medicine}

Traditional Bulgarian medicine uses the berries (Fructus ebuli) and rhizomes (Radix ebuli) but less commonly the flowers (Flores ebuli) (26). Traditional medicinal usage of different parts of the herb is

Table 1. SE applications in traditional medicine

\begin{tabular}{|c|c|c|c|}
\hline References & $\begin{array}{l}\text { Used plant } \\
\text { parts }\end{array}$ & $\begin{array}{l}\text { Form of application/ } \\
\text { preparation }\end{array}$ & Actions/Treatment \\
\hline Dimkov (14) & $\mathrm{F}$ & ${ }^{1} \mathrm{jam}$ & tbc, hemorrhoids \\
\hline Kültür (27) & $\mathrm{F}$ & ${ }^{1}$ decoction, ${ }^{1}$ fresh & hemorrhoids, gastric pain \\
\hline El Beyrouthy et al. (20) & $\mathrm{F}$ & $\begin{array}{l}{ }^{2} \text { fresh, }{ }^{2} \text { decoction } \\
\text { bath }\end{array}$ & rheumatoid arthritis \\
\hline Nikolov (30) & $\mathrm{F}$ & ${ }^{1}$ syrup & $\begin{array}{l}\text { appetite stimulating, toning, } \\
\text { hematopoietic }\end{array}$ \\
\hline Dimkov (14) & $\mathrm{Fl}$ & ${ }^{1}$ decoction & diuretic, diaphoretic \\
\hline Kültür (27) & $\mathrm{Fl}$ & ${ }^{1}$ decoction & cough \\
\hline El Beyrouthy et al. (20) & $\mathrm{Fl}$ & ${ }^{1}$ decoction & gout, rheumatoid arthritis \\
\hline Dimkov (14) & $\mathrm{L}$ & ${ }^{1}$ tea & influenza \\
\hline Kültür (27); El Beyrouthy et al. (20) & $\mathrm{L}$ & ${ }^{2}$ decoction, ${ }^{2}$ fresh & rheumatoid arthritis, insect bites \\
\hline Kültür (27) & Ls & ${ }^{2}$ decoction & snake bites \\
\hline Kültür (27) & Ap & ${ }^{2}$ poultice, ${ }^{2}$ fresh & $\begin{array}{l}\text { wounds, rheumatoid arthritis, } \\
\text { snake bites, }\end{array}$ \\
\hline Kültür (27) & Ap & ${ }^{1}$ decoction & gastric pain \\
\hline El Beyrouthy et al. (20) & Ap & ${ }^{2}$ decoction bath & rheumatoid arthritis \\
\hline Dimkov (14) & $\mathrm{R}$ & ${ }^{1}$ decoction & kidney diseases \\
\hline Kültür (27) & $\mathrm{R}$ & $\begin{array}{l}{ }^{2} \text { poultice, }{ }^{2} \text { decoction } \\
\text { bath }\end{array}$ & rheumatoid arthritis, analgesic \\
\hline Saric-Kundalic et al. (36) & $\mathrm{Wp}$ & ${ }^{2}$ fresh & snake bites, insect bites \\
\hline Ahtardzhiev (2) & $\mathrm{Wp}$ & $\begin{array}{l}{ }^{2} \text { poultice, }{ }^{2} \text { decoction } \\
\text { bath }\end{array}$ & $\begin{array}{l}\text { rheumatoid arthritis, neuralgia, } \\
\text { catarrh }\end{array}$ \\
\hline
\end{tabular}

Legend: F, fruits; Fl, flowers; Ap, aerial parts; $L$, leaves; Ls, leafy stems; $R$, roots; $W p$, whole plant ${ }^{1}$ oral administration, ${ }^{2}$ external application 
summarized in Table 1. It is a poorly studied species known for its healing effects in inflammation-related gastrointestinal diseases $(14,27)$. Berries are said to have diuretic, antiseptic, tonic and purgative activity. Only ripe berries, which do not contain any toxic glycoside sambunigrin, may be used (3). The dried roots are a source for preparation of one of the best remedies for dropsy (14).

\section{Phytochemical composition}

Phytochemical composition differs in the different parts and extracts of the plant. Flowers, fruits and roots contain different groups of compounds. The most specific ones are briefly presented in Table 2 . The content of flavanoids, anthocyanins, vitamin C, steroids, tannins, glycosides, cardiac glycosides, caffeic acid derivatives, chlorogenic acid, volatile substances, ursolic acid and phenols has been previously reported $(17,19,33,37,39-41,44)$ (Table 3). The plant contains type 1 and type 2 ribosome inactivating proteins (RIPs) and lectins as well (Table 3). compounds to quench free radicals $(23,41)$. The report about SE fruit aqueous extract modulating antioxidant genes expression presents other possible mechanism of its AOA (42). This effect is most likely mediated by polyphenol compounds in the extract $(28,29)$.

\section{Antiinflammatory activity}

Nitric oxide (NO) is also implicated in inflammation and other pathology, therefore, the very powerful radical scavenging activity of SE fruit extract may predict for and explain its antiinflammatory activity (19). Different SE extracts produce significant inhibition of inflicted edema and wound healing activity in animal models $(15,16,44)$. A similar effect of root extract with additional antinociceptive activity is reported, too (1). One of the first studies of SE effects on cell culture model demonstrates that the extracts from leaves and flowers are effective in suppression of IL1 $\alpha$, IL1 $\beta$, and TNFa biosynthesis (45). The plant exhibits its

Table 2. Phytochemical composition of different SE parts

\section{\begin{tabular}{l|l|l} 
References & Plant parts & Phytochemical composition
\end{tabular}}

Pieri et al. (32); $\quad$ Fl essential oils, sugars, cyanogenic glycosides

Staneva et al. (39)

Pribela et al. (33); $\quad$ F $\quad$ anthocyanins, sugars, valerianic acid, malic acid, tartaric acid,

Staneva et al. (39) tannins, pectin, resins, vitamin C

Staneva et al. (39) $\quad \mathrm{R} \quad$ tannins, saponins

Legend: $F$, fruits; Fl, flowers; $R$, roots

\section{SE biological activities}

The biological activities of SE vary in different extracts depending on their phytochemical content. Recent scientific achievements in this field are summarized in Table 4. These extracts exert high antioxidant, antiinflammatory, antiarthritic, antinociceptive and antimicrobial activities (1,1519,23,37,40-42,44,45). Latest investigations suggest a possible anticancer activity, too $(4,5,10,38)$.

\section{Antioxidant activity}

Many studies report in vitro antioxidant activity (AOA) of SE extracts $(17-19,23,41)$. Some of them establish a strong correlation with total polyphenol and anthocyanin content indicating the role of these antiinflammatory activity by inhibition of TNFainduced gene expression of vascular cell adhesion molecule 1 (VCAM-1), too (37). VCAM-1 is associated with a variety of chronic inflammatory disorders, making it a target for therapeutic intervention (6). This latest study supports traditional use of plant extracts and preparations rich in ursolic acid for the treatment of chronic inflammatory processes.

\section{Anticancer properties}

Immunotoxic conjugates composed by SE RIP ebulin 1 as a toxic moiety or mucin-binding lectin SELld (dimeric D-galactose and mucin-binding lectin) are effective inhibitors of protein synthesis and/or cell viability in many types of cancer cell lines 
Table 3. Phytochemical composition of different SE extracts

\begin{tabular}{|c|c|c|c|}
\hline References & $\begin{array}{l}\text { Extract (plant } \\
\text { part) }\end{array}$ & Phytochemical composition & Method \\
\hline Yesilada (44) & (Ap) $\mathrm{MeOH}$ ext & chlorogenic acid & ${ }^{1} \mathrm{H},{ }^{13} \mathrm{C}, 2 \mathrm{D}-\mathrm{NMR}$ \\
\hline Pribela et al. (33) & $\begin{array}{l}\text { (F) pentane-di- } \\
\text { ethyl etheric ext }\end{array}$ & $\begin{array}{l}\text { eugenol }(26,8 \%) \text {, valeric acid }(16,1 \%) \text {, methyl salic- } \\
\text { ylate, hexane-ol, } 2 \text {-hexen-1-ol, pentadecan-oic acid, } \\
\text { 2-hexenal. citronellal (3,7-dimethyl-6-octen-1-ol), } \\
\text { methyl palmitate, } 7 \text {-methyleicosane and methyl li- } \\
\text { noleate }(1-10 \%)\end{array}$ & Gas chrm. \\
\hline $\begin{array}{l}\text { Ebrahimzadeh et } \\
\text { al. (17) }\end{array}$ & $\begin{array}{l}\text { (F) AQ and } \\
\mathrm{MeOH} \text { ext }\end{array}$ & polyphenols and flavonoids & $\begin{array}{l}\text { colorimetric (Fo- } \\
\text { lin Ciocalteu and } \\
\mathrm{AlCl} 3 \text { ) }\end{array}$ \\
\hline $\begin{array}{l}\text { Ebrahimzadeh et } \\
\text { al. (19) }\end{array}$ & (F) aqueous & polyphenols and flavonoids & $\begin{array}{l}\text { colorimetric (Fo- } \\
\text { lin Ciocalteu and } \\
\mathrm{AlCl}_{3} \text { ) }\end{array}$ \\
\hline Tasinov et al. (41) & $\begin{array}{l}\text { (F) AQ and } \\
\mathrm{MeOH} \text { ext }\end{array}$ & polyphenols and anthocyanins & $\begin{array}{l}\text { colorimet- } \\
\text { ric method (Fo- } \\
\text { lin-Ciocalteu, } \\
\text { pH-differential) }\end{array}$ \\
\hline Suntar et al. (40) & (L) $\mathrm{MeOH}$ ext & quercetin 3-O-glucoside & HPLC, NMR \\
\hline $\begin{array}{l}\text { Schwaiger et al. } \\
\text { (37) }\end{array}$ & $\begin{array}{l}\text { (L) diethyl ether } \\
\text { fr }\end{array}$ & ursolic acid & NMR, HSCCC \\
\hline Pieri et al. (32) & (L) NA & $\begin{array}{l}10 \text { and 7-O-acetylpatrinoside-aglycone-11-O-[4“- } \\
\text { O-acetyl-alpha-L-rhamnopyranosyl-(1-->2)-beta- } \\
\text { D-ribohexo-3-ulopyranoside], 10-O-acetylpatrino- } \\
\text { side-aglycone-11-O-[alpha-L-rhamnopyranosyl- } \\
\text { (1->2)-beta-D-ribohexo-3-ulopyranoside], patrino- } \\
\text { side-aglycone-11-O-[4“-O-acetyl-alpha-L-rham- } \\
\text { nopyranosyl-(1-->2)-beta-D-ribohexo-3-ulopy- } \\
\text { ranoside], 10-O-acetylpatrinoside-aglycone-11-O- } \\
\text { [4“-O-acetyl-alpha-L-rhamnopyranosyl-(1->2)-be- } \\
\text { ta-D-glucopyranoside], and patrinoside-aglycone- } \\
\text { 11-O-2‘-deoxy-beta-D-glucopyranoside }\end{array}$ & $\begin{array}{l}1 \mathrm{D}-\text { and } 2 \mathrm{D}-\mathrm{NMR} \\
\text { spctr., mass spc- } \\
\text { tr., and chemical } \\
\text { degradation }\end{array}$ \\
\hline $\begin{array}{l}\text { De Benito et al. } \\
\text { (13) }\end{array}$ & (L) & Type 1 RIPs: Ebulitins $\alpha, \beta$ and $\gamma$ & chrm. \\
\hline Girbes et al. (21) & $(\mathrm{L})$ & Heterodimeric type 2 RIPs: Ebulin 1 & affinity chrm. \\
\hline Citores et al. (9) & (F) & Ebulin $\mathrm{f}$ & NA \\
\hline Citores et al. (8) & $(\mathrm{R})$ & Ebulins r1 and r2 & NA \\
\hline Iglesias et al. (24) & (R) & Tetrameric type 2 RIPs: SEA & mass spctr. \\
\hline Citores et al. (11) & $(\mathrm{L})$ & Monomeric lectins: SELlm & mass spctr. \\
\hline Citores et al. (8) & (R) & SEA II & NA \\
\hline Rojo et al. (35) & $(\mathrm{L})$ & Homodimeric lectins: SELld & NA \\
\hline Citores et al. (9) & $(\mathrm{F})$ & SELfd & NA \\
\hline
\end{tabular}

Legend: F, fruits; Ap, aerial parts; L, leaves; $R$, roots; $A Q$, aqueous; $\mathrm{MeOH}$, methanol; ext, extract; fr, fraction; spctr., spectroscopy; chrm., chromatography; NMR, nuclear magnetic resonance; HPLC, high-performance liquid chromatography; HSCCC, high-speed counter-current chromatography; NA, not available; SEA, Sambucus ebulus sialic acid-binding four-chain lectin; SELlm, Sambucus ebulus monomeric d-galactose binding lectin; SEA II, Sambucus ebulus monomeric N-Ac-galactosamine-binding lectin; SELld, Sambucus ebulus dimeric d-galactose and mucin-binding lectin; SELfd, Sambucus ebulus homodimeric D-galactose-binding lectin. 
$(4,5,10)$. Ethyl acetate SE extracts possess a lower IC50 in cancer cell lines in comparison with the normal cell lines (38).

\section{Antimicrobial activity}

Staphylococcus aureus (S. aureus) is one of the most common Staphylococcus species causing infections $(12,25)$. Ethanol extract from SE leaves demonstrates a significant inhibition of $\delta$-hemolysin production in a methicillin-resistant $S$. aureus isolate, thus proving a strong antimicrobial activity (34). Extracts from herbaceous parts exert antiHelicobacter pylori activity (46). This study confirms the traditional use of such extracts as a remedy for treatment of gastric disturbances associated with inflammation, including peptic ulcers $(14,29)$.

\section{CONCLUSION}

The high AOA, along with the proven antiinflammatory properties of SE imply the usage of the plant in various pathological conditions involving oxidative stress and inflammation. Studies revealing the possibilities for the application of SE derivatives in cancer therapy should continue, as scientific data indicate the plant's potential to reduce effectively cancer cell lines viability via protein synthesis inhibition.

In Bulgaria and in the other Balkan countries, there is a common use of traditional medicine along with a consumption of tea, syrups, and jams in everyday life. This suggests a need for further research in order to clarify the effects and mechanisms of SE influence on human health.

\section{REFERENCES}

1. Ahmadiani, A., M. Fereidoni, S. Semnanian, M. Kamalinejad, S. Saremi. Antinociceptive and antiinflammatory effects of Sambucus ebulus rhizome extract in rats.- J. Ethnopharmacol., 61, 1998, No 3, 229-235.

2. Ahtardzhiev, H. Pharmacognosy. Sofia, Medicina i fizkultura, 1975 (in Bulgarian).

3. Asenov, I., Ch. Gusev, G. Kitanov, S. Nikolov, T. Petkov. Herbs. A guide for harvesting and primary processing of medicinal plants. Sofia, Biler, 1998 (in Bulgarian).

4. Benitez, J., M. A. Rojo, R. Munoz, J. M. Ferreras, P. Jimenez, T. Girbes. Design and cytotoxicity analysis of a conjugate containing the new $\mathrm{D}$ - galactose-binding lectin SELld and the non-toxic type 2 ribosome-inactivating protein nigrin b.Lett. Drug Des. Discov., 4, 2004, No 1, 35-44.

5. Benitez, J., J. M., Ferreras, R. Munoz, Y. Arias, R. Iglesias, M. Cordoba-Diaz, et al. Cytotoxicity of an ebulin l-anti-human CD105 immunotoxin on mouse fibroblasts (L929) and rat myoblasts (L6E9) cells expressing human CD105.- Med. Chem., 1, 2005, No 1, 65-70.

6. Besemer, J., H. Harant, S. Wang, B. Oberhauser, K. Marquardt, C. A. Foster, et al. Selective inhibition of cotranslational translocation of vascular cell adhesion molecule 1.- Nature, 436, 2005, No 7048, 290-293.

7. Bolli, R. Revision of the genus Sambucus.- Diss. Bot., 223, 1994, 1-256.

8. Citores, L., F. M. De Benito, R. Iglesias, J. M. Ferreras, P. Argueso, P. Jimenez, et al. Characterization of a new non-toxic two-chain ribosome-inactivating protein and a structurallyrelated lectin from rhizomes of dwarf elder (Sambucus ebulus L.).- Cell. Mol. Biol., 43, 1997, No 4, 485-499.

9. Citores, L., F. M. De Benito, R. Iglesias, F. J. Miguel, P. Argueso, P. Jimenez, et al. Presence of polymerized and free forms of the non-toxic type 2 ribosome-inactivating protein ebulin and a structurally related new homodimeric lectin in fruits of Sambucus ebulus L.- Planta, 204, 1998, No 3, 310-319.

10. Citores, L., J. M. Ferreras, R. Munoz, J. Benitez, P. Jimenez, T. Girbes. Targeting cancer cells with transferrin conjugates containing the non-toxic type 2 ribosome-inactivating proteins nigrin $\mathrm{b}$ or ebulin 1.- Cancer Lett., 184, 2002, No 1, 29-35.

11. Citores, L., M. A. Rojo, P. Jimenez, J. M. Ferreras, R. Iglesias, I. Aranguez, et al. Transient occurrence of an ebulin-related D-galactose-lectin in shoots of Sambucus ebulus L.- Phytochemistry, 69, 2008, No 4, 857-864.

12. Cole, A. M., S. Tahk, A. Oren, D. Yoshioka, Y. Kim, A. Park, et al. Determinants of Staphylococcus aureus nasal carriage.- Clin. Diagn. Lab. Immunol., 8, 2001, No 6, 1064-1069.

13. De Benito, F. M., L. Citores, R. Iglesias, J. M. Ferreras, F. Soriano, J. Arias, et al. Ebulitins: a new family of type 1 ribosome-inactivating proteins (rRNA N-glycosidases) from leaves of Sambucus ebulus L. that coexist with the type 2 ribosome- 
Oskan Tasinov, Yoana Kiselova-Kaneva, Diana Ivanova

inactivating protein ebulin 1.- FEBS Lett., 360, 1995, №3, 299-302.

14. Dimkov, P. Bulgarian folk medicine. Sofia, BAS, 1977 (in Bulgarian).

15. Ebrahimzadeh, M. A., M. Mahmoudi, E. Salimi. Antiinflammatory activity of Sambucus ebulus hexane extracts.- Fitoterapia, 77, 2006, No 2, 146-148.

16. Ebrahimzadeh, M. A., M. Mahmoudi, M. Karami, S. Saeedi, A. H. Ahmadi, E. Salimi. Separation of active and toxic portions in Sambucus ebulus.- Pak. J. Biol. Sci., 10, 2007, No 22, 4171-4173.

17. Ebrahimzadeh, M. A., F. Pourmorad, A. R. Bekhradnia. Iron chelating activity, phenol and flavonoid content of some medicinal plants from Iran.- Afr. J. Biotechnol., 7, 2008, No 18, 3188-3192.

18. Ebrahimzadeh, M. A., S. F. Nabavi, S. M. Nabavi. Antioxidant activities of methanol extract of Sambucus ebulus flower.- Pak. J. Biol. Sci., 12, 2009, No 5, 447-450.

19. Ebrahimzadeh, M. A., S. F. Nabavi, S. M. Nabavi, F. Pourmorad. Nitric oxide radical scavenging potential of some Elburz medicinal plants.- Afr. J. Biotechnol., 9, 2010, No 32, 5212-5217.

20. El Beyrouthy, M., N. Arnold, A. Delelis-Dusollier, F. Dupont. Plants used as remedies antirheumatic and antineuralgic in the traditional medicine of Lebanon.- J. Ethnopharmacol., 120, 2008, No 3, 315-334.

21. Girbes, T., L. Citores, J. M. Ferreras, R. Munoz, M. A. Rojo, F. J. Arias, et al. Ebulin 1, a nontoxic novel type 2 ribosome-inactivating protein from Sambucus ebulus L. leaves.- J. Biol. Chem., 268, 1993, No 24, 18195-18199.

22. Guarrera, P. M. Traditional antihelmintic, antiparasitic and repellent uses of plants in Central Italy.- J. Ethnopharmacol., 68, 1999, No 1-3, 183-192.

23. Hosseinimehr, S. J., F. Pourmorad, N. Shahabimajd, K. Shahrbandy, R. Hosseinzadeh. In vitro antioxidant activity of Polygonium hyrcanicum, Centaurea depressa, Sambucus ebulus, Mentha spicata and Phytolacca americana.- Pak. J. Biol. Sci., 10, 2007, No 4, 637-640.

24. Iglesias, R., L. Citores, J. M. Ferreras, Y. Perez, P. Jimenez, M. J. Gayoso, et al. Sialic acid-binding dwarf elder four-chain lectin displays nucleic acid N-glycosidase activity.- Biochimie, 92, 2010, No 1, 71-80.
25. Kluytmans, J., A. van Belkum, H. Verbrugh. Nasal carriage of Staphylococcus aureus: epidemiology, underlying mechanisms, and associated risks.Clin. Microbiol. Rev., 10, 1997, No 3, 505-520.

26. Kozhuharov, S., ed. Definer of vascular plants in Bulgaria. Sofia, Nauka i izkustvo, 1992 (in Bulgarian).

27. Kültür, S. Medicinal plants used in Kırklareli Province (Turkey).- J. Ethnopharmacol., 111, 2007, No 2, 341-364.

28. Moskaug, J. O., H. Carlsen, M. C. Myhrstad, R. Blomhoff. Polyphenols and glutathione synthesis regulation.- Am. J. Clin. Nutr., 81, 2005, Suppl. 1, 277S-283S.

29. Myhrstad, M., H. Carlsen, O. Nordström, R. Blomhoff, J. O. Moskaug. Flavonoids increase the intracellular glutathione level by transactivation of the $\gamma$-glutamylcysteine synthetase catalytical subunit promoter.- Free Rad. Biol. Med., 32, 2002, No 5, 386-393.

30. Nikolov, S. Specialized encyclopedia of medicinal plants in Bulgaria. Sofia, Trud, 2007 (in Bulgarian).

31. Petkov, V. Bulgarian traditional medicine: a source of ideas for phytopharmacological investigations.J. Ethnopharmacol., 15, 1986, No 2, 121-132.

32. Pieri, V, S. Schwaiger, E. P. Ellmerer, H. Stuppner. Iridoid glycosides from the leaves of Sambucus ebulus.- J. Nat. Prod., 72, 2009, No 10, 1798-1803.

33. Pribela, A, J. Durcanska, J. Piry, J. Karovicova. Volatile substances of dwarf elder (Sambucus ebulus) fruits.- Biologia, Ser. C., 47, 1992, No 3, 225-230.

34. Quave, C. L., L. R. Plano, B. C. Bennett. Quorum sensing inhibitors of Staphylococcus aureus from Italian medicinal plants.- Planta Med., 77, 2011, No 2, 188-95.

35. Rojo, M. A., L. Citores, F. J. Arias, J. M. Ferreras, P. Jimenez, T. Girbes. cDNA molecular cloning and seasonal accumulation of an ebulin l-related dimeric lectin of dwarf elder (Sambucus ebulus L) leaves.- Int. J. Biochem. Cell Biol., 35, 2003, No 7, 1061-1065.

36. Saric-Kundalic, B., C. Dobes, V. Klatte-Asselmeyer, J. Saukel. Ethnobotanical study on medicinal use of wild and cultivated plants in middle, south and west Bosnia and Herzegovina.- J. Ethnopharmacol., 31, 2010, No 1, 33-55. 
37. Schwaiger, S., I. Zeller, P. Polzelbauer, S. Frotschnig, G. Laufer, B. Messner, et al. Identification and pharmacological characterization of the antiinflammatory principal of the leaves of dwarf elder (Sambucus ebulus L.).- J. Ethnopharmacol., 133, 2011, No 2, 704-709.

38. Shokrzadeh, M., S. S. Saeedi Saravi, M. Mirzayi. Cytotoxic effects of ethyl acetate extract of Sambucus ebulus compared with etoposide on normal and cancer cell lines.- Pharmacognosy Magazine, 5, 2009, No 20, 316-319.

39. Staneva, D., D. Panova, L. Raynova, I. Asenov. Herbs in every home. Sofia, Medicina i fizkultura, 1986 (in Bulgarian).

40. Suntar, I. P., E. K. Akkol, F. N. Yalcin, U. Koca, H. Keleş, E. Yesilada. Wound healing potential of Sambucus ebulus L. leaves and isolation of an active component, quercetin 3-O-glucoside.- J. Ethnopharmacol., 129, 2010, No 1, 106-114.

41. Tasinov, O., Y. Kiselova-Kaneva, D. Ivanova. Antioxidant activity, total polyphenol content and anthocyanins content of Sambucus ebulus L. aqueous and aqueous-ethanolic extracts depend on the type and concentration of extragent.- Sci. Technol., 2, 2012a, No 1, 37-41.
42. Tasinov, O., Y. Kiselova-Kaneva, D. Ivanova. Sambucus ebulus L. fruit aqueous infusion modulates GCL and GPx4 gene expression.- Bulg. J. Agric. Sci., 19, 2013b, No 2 (in press)

43. Westwood, J. Albion. A guide to legendary Britain. London, Grafton Books, 1985, 103 p.

44. Yesilada, E. Evaluation of the anti-inflammatory activity of the Turkish medicinal plant Sambucus ebulus.- Chem. Nat. Compounds, 33, 1997, No 5, 539-540.

45. Yesilada, E., O. Ustün, E. Sezik, Y. Takaishi, Y. Ono, G. Honda. Inhibitory effects of Turkish folk remedies on inflammatory cytokines: interleukin$1 \alpha$, interleukin- $1 \beta$ and tumor necrosis factor $\alpha .-J$. Ethnopharmacol., 58, 1997, No 1, 59-73.

46. Yesilada, E., I. Gürbüz, H. Shibata. Screening of Turkish anti-ulcerogenic folk remedies for antiHelicobacter pylori activity.- J. Ethnopharmacol., 66, 1999, No 3, 289-293. 